UDK 631.421:631.427:504.5:711.55

DOI: $10.15587 / 2519-8025.2020 .211556$

\title{
DETERMINATION OF THE LEVEL OF TOXICITY OF THE SOILS OF RECREATIONAL AREAS OF ODESSA CITY BY BIOTESTING METHODS
}

\author{
A. Khokhryakova
}

The aim of the research - assessment of the level of chemical contamination of soils with heavy metals $(\mathrm{Cd}, \mathrm{Pb}, \mathrm{Cu}$, $\mathrm{Zn}$ ) and assessment of the toxicity of the soils of the recreational areas of Odessa as an indicator of unfavorable effect on the health of the population by the integral method of analyzing the quality of the environment object - the biotesting method, during which laboratory standardized test objects are used.

Materials and methods. In this research biotesting of different soil samples was done to determine their phytotoxicity according to SSU ISO 11269-1: 2004 and SSU ISO 11269-2: 2002. The content of mobile forms of heavy metals Cd, Pb, $\mathrm{Cu}, \mathrm{Zn}$ was determined according to SSU 4770.3: 2007, SSU 4770.9: 2007, SSU 4770.6: 2007, SSU 4770.2: 2007 with ammonium acetate buffer $\mathrm{pH} 4.8$ on an atomic absorption spectrophotometer AAS 115. Also determined: the content of humus according to Tyurin (SSU 4289: 2004), nitrogen by nitrifying ability (GOST 26951-86), phosphorus and potassium according to Machigin (SSU 4114-2002); pHN2O (SSU 8346: 2015), the composition of the salt extract (according to SSU 7943: 2015, SSU 7908: 2015, SSU 7909: 2015, SSU 7944: 2015, SSU 7945: 2015); granulometric composition according to Kaczynski (SSU 4730: 2007); the composition of the absorbed bases Ca, Mg, Na (according to GOST 26487-85, SSU 7912: 2015).

Results. Soils of the coastal slopes and the largest parks of Odessa, which are located in the areas of influence of highways different in traffic intensity and load, was selected as the objects of the research. In the key areas 8 full-profile soil sections and two diggings were laid according to generally accepted methods. In recreazems, the maximum permissible concentration of Zinc content was found to be three times higher (key areas 14-PP, section P9), $74 \%$ of the selected samples had a very high level of Lead content, the maximum permissible concentration was exceeded. Exceedance of the maximum permissible concentration of Cadmium and Copper was not detected. In the research soft wheat seeds Triticum aestivum, Antonovka sort and barley Hordéum vulgáre, Dostoiniy variety, was selected as test cultures, test reactions in response to anthropogenic impact (laboratory germination, vigor, length of underground and aboveground part of seedlings) were recorded. The influence on morphological and physiological characteristics of test cultures, which are shown in inhibition of plant, yellowing elevated part of some test cultures was revealed. The toxicity of the soils, that was studied for growth inhibition of the aboveground part is assessed by phytotoxic activity mainly as highly toxic $(I c=64-72 \%)$. According to growth inhibition of the underground part of wheat is moderately toxic $(I k=48-58 \%)$. With regard to barley, a non-toxic effect by phytotoxic activity was revealed (Ic $=27-44 \%$ and $I k=39-49 \%)$, which is indicative of the greater durability of barley seeds to contamination by heavy metals. When determining soils toxicity, the most indicative is the use of wheat in biotesting compared to barley.

Conclusions. Soils according to the mean values of growth inhibition indices have the following toxicity: recreazems $(I c=-65 \%$, I $k=-55 \%)$ - hillozems (Ic=-64\%, I $k=-57 \%)$. Recreazems, in which an excess of maximum permissible concentration of Zinc was found (4 times more in the Victory park, 2 times in "Airport's", 1.5 times in parks "named after M. Gorky" and "named after T. Shevchenko"), and of Lead (6 times more in the park "Dukivskiy Sad"), have the highest indicators of phytotoxicity of aboveground part of wheat and are assessed as highly toxic (Ic = 64-72 \%). It was revealed that the high content of nutrients in the soils of parks (recreazems) does not eliminate the toxic effects of heavy metals

Keywords: phytotoxicity, biotesting, recreazems, Odessa, growth inhibition, soil contamination

Copyright $(\mathrm{C}) 2020$, A. Khokhryakova. This is an open access article under the CC BY license (http://creativecommons.org/licenses/by/4.0).

\section{Introduction}

The increase in the area of settlements due to the areas that have an active-functional surface and are usually represented by intact natural and plowed agricultural lands, leads to a change in the ecological potential of soils on a global scale. One of the tasks of soil scientists is to predict the effects of urbanization on global changes in the ecological functions of soil cover. The most complete development of research on urban ecosystems and the role of soils in them has been achieved by scientists from Poland, Germany, USA, Russia [1-5], in Ukraine is currently undergoing the development of methodological principles for studying the urban ecosystem [6].

Soil in the city is one of the main natural resources, which provides the necessary level of socioeconomic development of society, performs specific sanitary and environmental functions in the city, which affect the health of the population [7]. An indicator of deep functional disturbances of urban soils is their contamination with heavy metals that enter the environment near highways as a result of fuel combustion, abrasion of 
mechanical parts of vehicles and road surface. As a result, most of the mobile forms of heavy metals are fixed in the soil-absorbing complex in the upper part of the profile of urban soils. Accumulation is facilitated by a neutral and slightly alkaline reaction of the soil solution and the content of humus in the soil. $\mathrm{Pb}, \mathrm{Cd}, \mathrm{Zn}, \mathrm{Cu}, \mathrm{Ni}$, $\mathrm{Cr}$, Co are distinguished among the main heavy metals, which are found along transport arteries in significant quantities [8]. The use of anti-icing compounds on sidewalks and roads in winter has an equally significant effect on urban soils. Thus, soils, on the one hand, are a buffer and geochemical barrier and prevent groundwater pollution, and on the other hand, are a constant source of pollutants in the atmosphere and plants.

Assessing the quality of the soil by determining the content of chemical elements and their compounds by physical and chemical methods provides information about their quantity, rather than the toxic effect on living organisms, especially plants. Biotesting is considered to be an effective method of assessing the potential danger of chemical, physical or biological impact on the soil [9]. Biotesting is an integrated method of analyzing the quality of an environmental object, which uses laboratory standardized test objects. Under the conditions of the experiment, their reactions in response to anthropogenic influence are recorded [10].

\section{Literary review}

One of the most relevant areas of urban soil research is to determine the main sources of heavy metals, analysis of their distribution in the natural environment, especially in soils $[11,12]$. Soil pollution changes the course of soil formation (inhibits it), sharply reduces soil productivity, causes the accumulation of pollutants in plants, from which they often enter the human body directly or indirectly (through plant and animal products). Another consequence of soil contamination with heavy metals is the weakening of self-cleaning of soils from pathogenic organisms, which are sources of dangerous diseases [13].

As a result of the negative impact of heavy metals, oil products and other pollutants on the components of the city's environment, there is a change in the activity of soil enzymes in urban areas. Studies [14] revealed a decrease in urease activity in urbanized soils of Mariupol by almost 3 times compared to background soils. It is established that the enzymatic activity of the city soils depends on the degree and type of anthropogenic impact. The greatest oppression is observed in soil-like formations, sealed soils. There is a close relationship between humus content and enzymatic activity in all soils, regardless of their origin (the higher the humus content, the higher the activity) $[15,16]$.

Along with the study of enzymatic activity, which correlates with the level of pollution and has a high variability in time and space, to assess the ecological status of soils in urban areas are widely used methods of biotesting using plants as test crops [17]. Biotesting methods are based on the feedback of living organisms to the negative effects of environmental pollutants, help to establish the level of toxicity of the environment. Various plants are used as a test system: common onion (Allium cepa) [18], radish (Raphanus sativus var. Sativus) [19], sugar sorghum (Sorghum sacchartum), watercress (Lepidium sativum) [20], common oat (Avena sativa L.) [21], annual aster (Callistephus chinensis (L.) Nees) and others [22]. As a result of this type of study, the limits of plant growth inhibition, their resistance to pollutants, soil phytotoxicity are established. The obtained data should be used when creating landscaping facilities in the city (especially when choosing the range of plants), measures to modernize greenery and reduce phytotoxicity of soils.

\section{The purpose and objectives of the study}

The main purpose of the study is to assess the level of chemical contamination of soils with heavy metals $(\mathrm{Cd}, \mathrm{Pb}, \mathrm{Cu}, \mathrm{Zn})$ and to assess the toxicity of soils in the parks of Odessa by biotesting methods.

To achieve this goal, the following tasks were solved:

1) research of the basic physical and chemical properties of soils of parks;

2) determination of indicators of heavy metals content in soils;

3 ) assessment of the ecological condition of the soils of the parks of the city of Odessa according to the main indicators (concentration coefficient $\mathrm{Kc}$, total indicators of pollution $\mathrm{Zc}$ );

4) conducting biotesting of soil samples of different parks of the city of Odessa with determination of their phytotoxicity.

\section{Materials and methods of research}

In this study, biotesting of different soil samples was determined to determine their phytotoxicity according to State Standards of Ukraine (SSU) ISO 11269-1: 2004 and SSU ISO 11269-2: 2002. The content of mobile forms of heavy metals $\mathrm{Cd}, \mathrm{Pb}, \mathrm{Cu}, \mathrm{Zn}$ was determined according to SSU 4770.3:2007, SSU 4770.9:2007, SSU 4770.6:2007, SSU 4770.2:2007 with ammonium acetate buffer $\mathrm{pH} 4.8$ on an atomic absorption spectrophotometer AAS 115. Also we determined content of humus according to Tyurin (SSU 4289:2004), nitrogen according to nitrification ability (GOST 26951-86), phosphorus and potassium according to Machigin (SSU 4114-2002); $\mathrm{pH}_{\mathrm{N} 2 \mathrm{O}}$ (SSU 8346:2015), the composition of the salt extract (according to SSU 7943:2015, SSU 7908:2015, SSU 7909:2015, SSU 7944:2015, SSU 7945:2015); granulometric composition according to Kaczynski (SSU 4730:2007); the composition of the absorbed bases $\mathrm{Ca}, \mathrm{Mg}, \mathrm{Na}$ (according to GOST 26487-85, SSU 7912:2015).

\section{Research results and their discussion}

The city of Odessa is located within the coastalestuary physical-geographical region of the Dniester-Bug steppe region of the Black Sea forest accumulative lowland. The zonal soils of the subzone of the Southern Steppe of Ukraine in the area of the Dniester-Bug accumulative forest plain are the southern chernozems, mainly low-humus heavy loam (agricultural soil group 71e).

The object of the study was selected soils of the largest parks in the city of Odessa, which are located in the areas of influence of highways, different in traffic intensity and load. 8 full-profile sections and two excavations were laid according to the generally accepted meth- 
ods. Key section 19-SSCh - P1 (sloping lands near the Chkalov Sanatorium). Key section 10-OR - P3 (square near the Odessa Regional Council, under the trees), P4 (square near the Odessa Regional Council, lawn). Key section 35-TR - P5 (park "Dukivskiy Sad", 69 Rozkydailivska Street). Key section 11-PDS - P6 (park
“Dukivskiy Sad"). Key section 12-M411BB - P7 (Memorial of 411 coast battery). Key section 13-PA - P8 (park near the Airport). Key section 14-PP - P9 ("Victory" park). Key section 15-PG - P1 (excavation of park "named after Gorky"). Key section 16-PSH - P2 (excavation of park "named after Shevchenko") (Fig. 1).

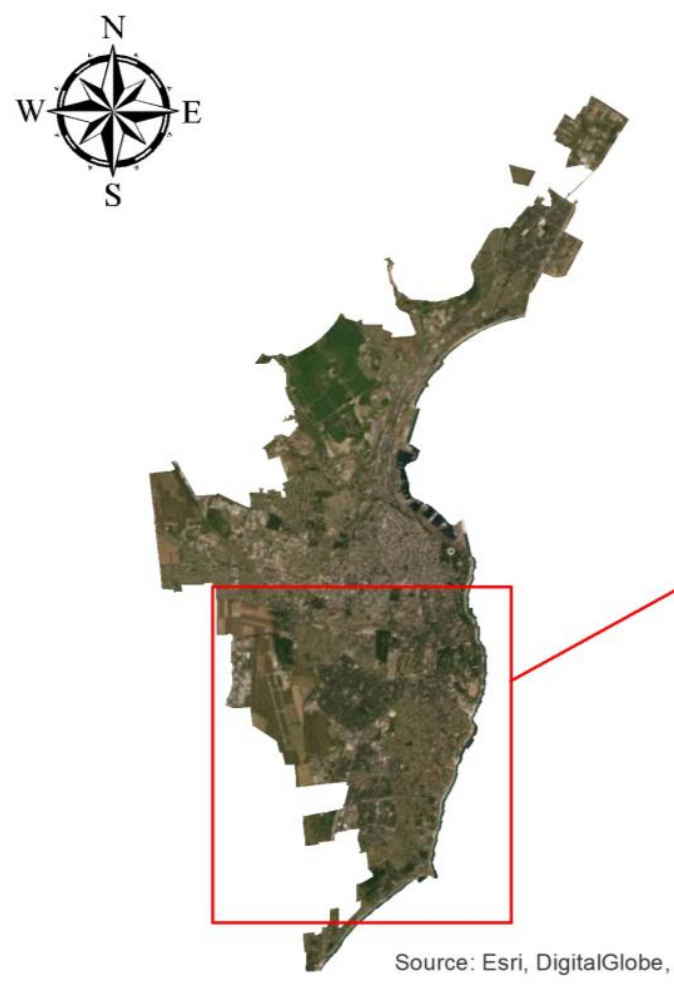

Legend

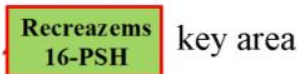

P 12 section number

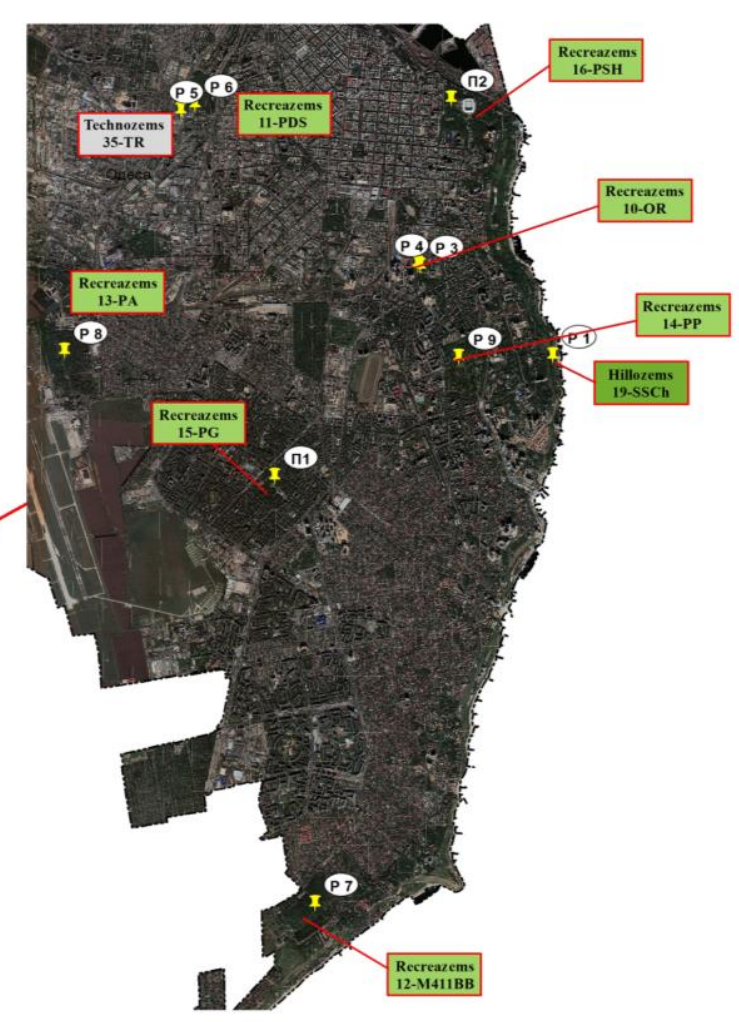

Source: Esri, DigitalGlobe,

$1: 25000$

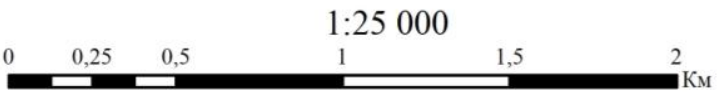

Fig. 1. Soil sampling sites

To compare our research on physical and chemical properties of soils of the city of Odessa, we used the average data obtained during the monitoring of soil condition by the Odessa branch of the State Institution "Institute of Soil Protection of Ukraine", namely the moni- toring site (MS) No. 17 in the village Lymanka of Ovidiopol district, which is represented by zonal soils southern loamy black soil (agricultural soil group 71e). The main physical and chemical properties of soils of recreational areas of the Odessa city are given in Table 1.

Table 1

Physical and chemical properties of soils of recreational areas of the Odessa

\begin{tabular}{|c|c|c|c|c|c|c|c|}
\hline \multirow{3}{*}{$\begin{array}{l}\text { No. soil } \\
\text { section }\end{array}$} & \multirow{3}{*}{$\begin{array}{c}\text { Depth of } \\
\text { sampling, cm }\end{array}$} & \multirow{3}{*}{ рНн2о } & \multirow{3}{*}{ Humus, $\%$} & \multirow{3}{*}{$\begin{array}{c}\text { The content of soil } \\
\text { particles }<0.01 \mathrm{~mm} \text {, } \\
\%\end{array}$} & \multicolumn{3}{|c|}{ Nutrients, $\mathrm{mg} / \mathrm{kg}$ of soil } \\
\hline & & & & & \multirow{2}{*}{ N-NO3 } & $\mathrm{P} 2 \mathrm{O} 5$ & $\mathrm{~K} 2 \mathrm{O}$ \\
\hline & & & & & & \multicolumn{2}{|c|}{ according to Machigin } \\
\hline $\mathrm{P} 1$ & $0-10$ & 7.10 & 4.76 & 36.11 & 13.62 & 22.27 & 332.13 \\
\hline P3 & $0-8$ & 7.20 & 2.88 & 36.85 & 2.37 & 54.97 & 332.55 \\
\hline $\mathrm{P} 4$ & $0-7$ & 7.10 & 5.08 & 34.89 & 68.73 & 71.41 & 674.17 \\
\hline P5 & $0-25$ & 7.10 & 3.09 & 37.62 & 10.12 & 32.82 & 311.76 \\
\hline P6 & $0-21$ & 6.80 & 3.96 & 43.09 & 16.03 & 71.91 & 1032.59 \\
\hline P7 & $0-45$ & 6.80 & 3.67 & 37.64 & 30.24 & 5.52 & 317.59 \\
\hline P8 & $0-30$ & 6.70 & 3.28 & 46.86 & 11.35 & 2.98 & 172.89 \\
\hline P9 & $0-50$ & 6.90 & 2.61 & 33.62 & 2.58 & 24.21 & 213.53 \\
\hline $\mathrm{P} 1$ & $0-20$ & 6.80 & 3.18 & 39.74 & 48.99 & 52.55 & 359.72 \\
\hline $\mathrm{P} 2$ & $0-20$ & 6.70 & 5.79 & 28.69 & 12.97 & 73.21 & 604.72 \\
\hline MS No. 17 & $0-40$ & 7.1 & 3.19 & 45.2 & 2.19 & 94.46 & 411.15 \\
\hline
\end{tabular}


Concentration coefficient $(\mathrm{Cc})$ and total pollution index $(\mathrm{Zc})$ were used to characterize the pollution of environmental objects [23]. To assess the ecological condition of soils, the total pollution index is calculated as the total number of concentration coefficients. The value of the concentration coefficient indicates the activity of the processes of leaching $(\mathrm{Cc}<1)$ and accumulation $(\mathrm{Cc}>1)$ of cations and anions of chemical elements in the genetic horizons of the soil [24]. Assessment of the ecological condition of the soil was performed by gradation: $\mathrm{Cc} \geq 5-$ unsatisfactory condition, Cc 3.0-5.0 - satisfactory, Cc 1.0-2.9 - normal, $\mathrm{Cc} \leq 1.0$ - optimal [25]. The calculation of the complex indicator of the total pollution $\mathrm{Zc}$ was carried out taking into account the geometric mean concentration coefficients of heavy metals on a geochemical basis. The total pollution rate $\mathrm{Zc}$ was estimated by gradation [26].

Maximum allowable concentration (MAC) of mobile forms of chemical elements extracted with ace-

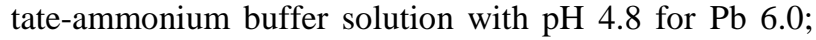

$\mathrm{Cd}-0.7 ; \mathrm{Zn}-23 ; \mathrm{Cu}-3.0$ [27]. The average content of heavy metals shows that in almost all parks there is an increase in their content. The indicators were not exceeded only for copper. In soil samples taken from the sloping areas near the sanatorium named after Chkalov (P1), there is an excess of MAC on the average value of $\mathrm{Zn}$ content in 6 times (Table 2).

Exceedance of MAC on the average value of $\mathrm{Zn}$ content in the samples taken from the park "Victory" (P9), 3 times; from the park near the Airport (P8) and "named after Shevchenko" (P2) - 1.5 times; from the park "Dyukivskiy Sad" (Rozkidaylivska, 69) (P5) 3 times. Exceeding the MAC on the average value of the content of $\mathrm{Pb}$ : the park "named after Gorky" (P1) 8 times, the park "Dyukivskiy Sad" (P6 and P6) - 3 and 5 times, respectively, the park "named after Shevchenko" (P2) -6.5 times, the square near the OOR (flower bed, lawn) (P4) - 1.7 times. A slight excess of cadmium content is found in soil samples from the "named after Gorky" and "named after Shevchenko".

Table 2

The content of heavy metals in soils

\begin{tabular}{|c|c|c|c|c|c|}
\hline \multirow{2}{*}{ No. of soil section } & \multirow{2}{*}{ Depth of sampling, cm } & \multicolumn{4}{|c|}{ Content in soils (mg / kg) } \\
\cline { 3 - 6 } & & \multicolumn{2}{|c|}{ heavy metals } & \multicolumn{3}{|c|}{ micronutrients } \\
\cline { 3 - 6 } & & $\mathrm{Pb}$ & $\mathrm{Cd}$ & $\mathrm{Zn}$ & $\mathrm{Cu}$ \\
\hline P1 & $0-10$ & 4.54 & 0.36 & 241.60 & 0.18 \\
\hline P3 & $0-8$ & 6.89 & 0.15 & 13.22 & 0.92 \\
\hline P4 & $0-7$ & 6.14 & 0.55 & 15.02 & 1.07 \\
\hline P5 & $0-25$ & 50.27 & 0.86 & 37.90 & 1.32 \\
\hline P6 & $0-21$ & 37.79 & 0.54 & 18.38 & 0.93 \\
\hline P7 & $0-45$ & 2.66 & 0.22 & 0.89 & 1.36 \\
\hline P8 & $0-30$ & 9.53 & 0.21 & 35.58 & 0.49 \\
\hline P9 & $0-50$ & 48.32 & 0.55 & 87.54 & 1.33 \\
\hline P1 & $0-20$ & 38.90 & 0.79 & 25.10 & 1.37 \\
\hline P2 & $0-20$ & 1.98 & 0.94 & 38.29 & 1.58 \\
\hline MS No. 17 & $0-40$ & 0.99 & 0.63 & 0.32 \\
\hline
\end{tabular}

According to the value of the concentration coefficient, in the territories of almost all parks $\mathrm{Cc}_{\mathrm{Cd}}(\mathrm{P} 9, \mathrm{P} 8$, P6, P7, P1, P4, P3, P5) and $\mathrm{Cc}_{\mathrm{Pb}}$ (P8, P7) less than 1, the content of these metals does not exceed MAC. Cd accumulation occurs in samples P1, P2, MS No. 17; Zn, $\mathrm{Cu}$ - in all soil samples; $\mathrm{Pb}-$ in all, but $\mathrm{P} 8$ and $\mathrm{P} 7$. According to the gradation [25], the ecological condition of the soils of parks P9, P8, P6, P1, P4, P3, P5 is optimal, $\mathrm{P} 1, \mathrm{P} 2$ and MS No. 17 - normal by the $\mathrm{Cc}_{\mathrm{Cd}}$ coefficient. According to $\mathrm{Cc}_{\mathrm{Cu}}$, all parks have an optimal ecological condition. According to $\mathrm{Cc}_{\mathrm{Pb}}$, the ecological condition of the soils of parks P9, P8, P7, MS No. 17 is optimal, P1, P4, P3 - normal, P6 and P5 - satisfactory, P1 and P2 unsatisfactory. According to $\mathrm{Cc}_{\mathrm{Zn}}$, the ecological condition of the soils of parks P6, P7, P4, P3, MS is optimal, P9, P8, P1, P2, P5 - normal, and P1 - unsatisfactory.

The calculation of the complex indicator of the total pollution $\mathrm{Zc}$ is carried out taking into account the geometric mean coefficients of concentration of heavy metals as a territory on a geochemical basis. According to the developed gradation [26] of pollution of the territory for the purpose of studying of a state of health of the population, it is defined that total indicators of pollution
$\mathrm{Zc}_{\mathrm{Zn}}, \mathrm{Zc}_{\mathrm{Cu}}, \mathrm{Zc}_{\mathrm{Cd}}$ are within admissible (weak) level of danger $(\mathrm{Zc}<16)$, and $\mathrm{Zc}_{\mathrm{Pb}}$ - within moderately dangerous level (Zc 16-32).

An effective method of assessing the potential hazard of chemical, physical or biological effects on the soil is biotesting - an integrated method of analyzing the quality of the environment, which uses laboratory standardized test objects.

Wheat and barley seeds were selected as test crops. During the experiment, test reactions in response to anthropogenic influence were recorded: laboratory germination, germination energy, length of underground and aboveground parts of seedlings, weight of plants in wet and air-dry state. The effect on the morphological and physiological characteristics of test cultures, manifested in the suppression of plants, yellowing of the aboveground part of some test cultures.

The studied soils differ in the content of not only pollutants, but also nutrients that affect plant growth. However, in those phases of development that were studied in biotesting, the vital activity of plants still depended almost entirely on the reserve nutrients in the seeds. This allowed to some extent to assess the impact on the course 
of germination of the content of heavy metals contained in the studied samples, and can inhibit the growth and development of plants.

Assessment of phototoxicity by Vasilchenko A.V. [28] was performed according to the criteria: $<20 \%$ - phytotoxic activity is not manifested (normal); $20-40 \%-$ weak phytotoxicity; 40-60\% - average; >60\% - strong phytotoxic activity. The criterion of toxic action is the inhibition of seedling growth by $50 \%$.

Assessment of soil toxicity was performed on seedlings of soft wheat seeds Triticum aestivum, Antonovka variety. Analysis of the average values of seedling parameters shows the influence of soil properties on the growth of underground and aboveground parts of winter wheat plants. The smallest values of root lengths differ seedlings in samples P1 and P5 - 11.16 and $11.43 \mathrm{~cm}$, respectively. In the control, the length of the roots was the maximum $-19.54 \mathrm{~cm}$. The influence of soil properties was confirmed by the results of analysis of variance $\left(\mathrm{F}_{\text {studied }}=38.0\right.$, at $\left.\mathrm{F}_{05}=1.57\right)$. All experimental variants are significantly inferior to the control over the average length of the root, i.e. in all studied soils there is inhibition of the growth of the underground part of wheat plants.

The degree of plant suppression is characterized by an indicator of phytoxicity that fluctuates inversely with the length of roots and / or seedlings. According to the level of nitrogen supply, which affects the mass of the root system, the control is significantly inferior to samples P3, P4, P1, P6, P7. The only exception is the soil from section P9. However, the depressing effect of heavy metals still manifested itself. The greatest inhibitory effect in terms of phytotoxicity is significantly observed in soil samples P9, P8, P6, P7, P2, P1, P4, P3 (Ik=52-67\%). Samples from the park "named after Gorky" (P1) and park "Dyukivskiy Sad", st. Rozkidaylivska, 69 (P5) evaluated for phytotoxic activity as having a slight toxic effect $(\mathrm{p}>0.05) \quad \mathrm{Xk} \pm \mathrm{mk}=19.54 \pm 0.31$; $\mathrm{X}_{\mathrm{P} 1} \pm \mathrm{m}_{\mathrm{P} 1}=11.16 \pm 0.42 ; \mathrm{X}_{\mathrm{P} 5} \pm \mathrm{m}_{\mathrm{P} 5}=11.43 \pm 0.37(\mathrm{Ik}=48-49 \%)$ (Table 3).

Table 3

Phytotoxic effect of HM in the soils of Odessa on the growth of soft wheat seedlings Triticum aestivum L.

\begin{tabular}{|c|c|c|c|c|c|}
\hline \multirow{2}{*}{ Soil sample } & \multicolumn{2}{|c|}{ Length, $\mathrm{cm}$} & \multicolumn{3}{|c|}{ Phytotoxic inhibitory activity, $\%$} \\
\hline & roots & aboveground part & roots, $+/-\mathrm{Ik}$ & aboveground part, +/- Is & half the sum \\
\hline Control & $19.54 \pm 0.31$ & $20.48 \pm 0.28$ & & & \\
\hline P9 & $12.76 \pm 0.44$ & $16.89 \pm 0.32$ & -56 & -72 & -64 \\
\hline P8 & $15.37 \pm 0.40$ & $15.23 \pm 0.21$ & -67 & -64 & -65.5 \\
\hline P6 & $12.35 \pm 0.37$ & $15.25 \pm 0.39$ & -53 & -65 & -59 \\
\hline P7 & $13.07 \pm 0.32$ & $15.37 \pm 0.35$ & -57 & -65 & -61 \\
\hline $\mathrm{P} 1$ & $11.16 \pm 0.42$ & $15.77 \pm 0.46$ & -48 & -65 & -56.5 \\
\hline $\mathrm{P} 2$ & $13.36 \pm 0.39$ & $16.15 \pm 0.20$ & -58 & -70 & -64 \\
\hline $\mathrm{P} 1$ & $13.19 \pm 0.45$ & $15.21 \pm 0.36$ & -57 & -64 & -60.5 \\
\hline $\mathrm{P} 4$ & $13.17 \pm 0.38$ & $15.48 \pm 0.52$ & -58 & -66 & -62 \\
\hline P3 & $12.27 \pm 0.32$ & $15.12 \pm 0.37$ & -52 & -64 & -58 \\
\hline P5 & $11.43 \pm 0.37$ & $13.79 \pm 0.30$ & -49 & -58 & -53.5 \\
\hline $\mathrm{HIP}_{05}$ & 0.83 & 0.76 & & & \\
\hline $\mathrm{F}_{\text {studied }}$ & 38.0 & 24.8 & & & \\
\hline $\mathrm{F}_{05}$ & 1.57 & 1.57 & & & \\
\hline
\end{tabular}

According to the effect on the root, samples P5 and $\mathrm{P} 1$ are phytotoxic, their phytotoxicity is determined by indices less than $50 \%$. The remaining samples are close to this value, but still do not cross the phytotoxicity limit. None of the samples was phytotoxic due to the influence on the development of shoots. Inhibition of wheat root growth is more pronounced than for shoots, the difference in soil phytotoxicity indices for roots and shoots is $9 \%$.

Analysis of the average values of the parameters of wheat seedlings shows that the phytotoxic activity of the aboveground part of wheat varies within $\mathrm{Ik}=58-72 \%$. The phytotoxic activity of the underground part of wheat varies within Ik=48-67 \% (Fig. 2).

The half-sum of the inhibition indices of the underground and aboveground part characterizes the total effect of heavy metals on plant growth. In terms of the total effect on root and shoot growth, the most phytotoxic were samples P5 and P1, with indices of 53.5 and $56.5 \%$, respectively, while for control, this figure is a total of $100 \%$.
Evaluation of soil toxicity on barley seed seedlings Hordéum vulgáre, variety Dostoiniy, also showed a significant effect of heavy metals on the growth of underground and aboveground parts of plants, this is confirmed by the results of analysis of variance. As in the case of wheat, the control was significantly detached from samples with a higher nitrogen content but also contaminated with HM. Analysis of the average values of the parameters of seedlings shows that the smallest values of root length are seedlings in the sample P6, P4, P1 and

$\mathrm{P} 5(\mathrm{p}<0.05) \mathrm{Xk} \pm \mathrm{mk}=14.03 \pm 0.21$

$\mathrm{X}_{\mathrm{P} 6} \pm \mathrm{m}_{\mathrm{P} 6}=10.10 \pm 0.30$

$\mathrm{X}_{\mathrm{P} 4} \pm \mathrm{m}_{\mathrm{P} 4}=10.10 \pm 0.42$;

$\mathrm{X}_{\mathrm{P} 1} \pm \mathrm{m}_{\mathrm{P} 1}=10.87 \pm 0.28$;

$\mathrm{X}_{\mathrm{P} 5} \pm \mathrm{m}_{\mathrm{P} 5}=11.07 \pm 0.27$.

Soil samples from the park near the Airport (P8) were evaluated for phytotoxic activity as having a slight toxic effect $(\mathrm{Ik}=54 \%)$. All recent soil samples were evaluated for phytotoxic activity as non-toxic (Ik=39-49\%) (Fig. 3). 


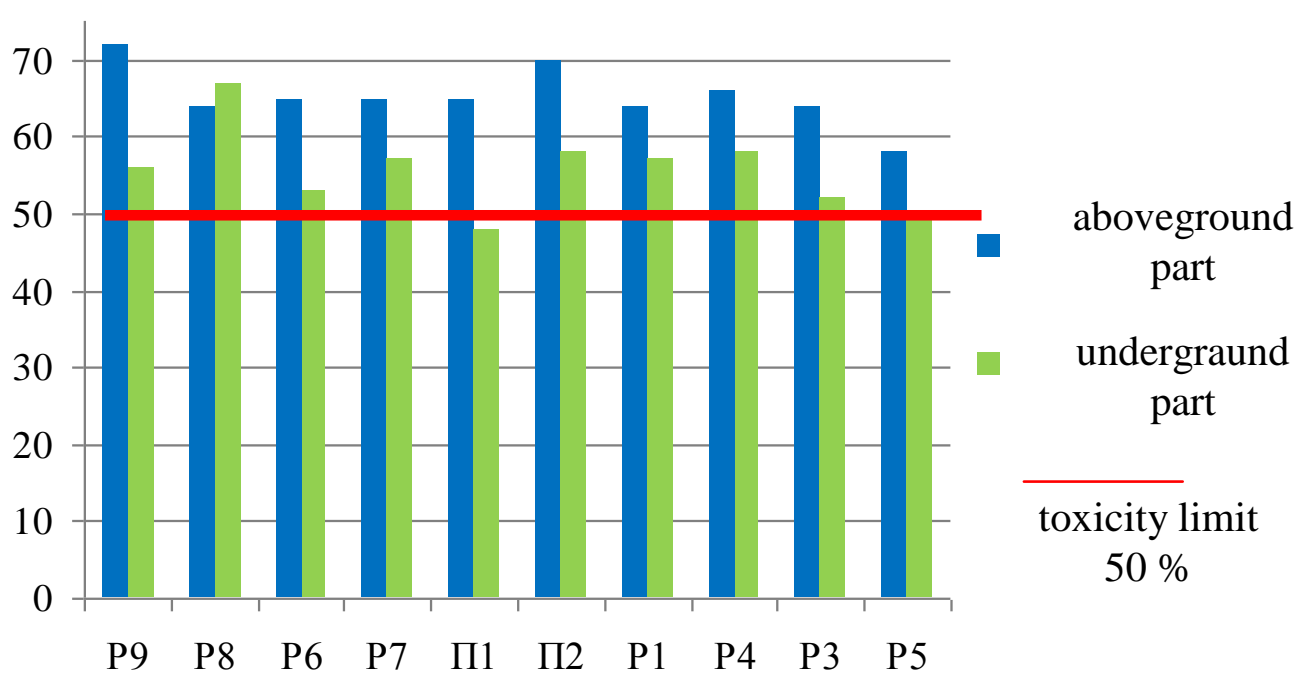

Fig. 2. Phytotoxic activity of growth inhibition of aboveground and underground part of wheat germ , $+/-$ Is and $\mathrm{Ik}, \%$

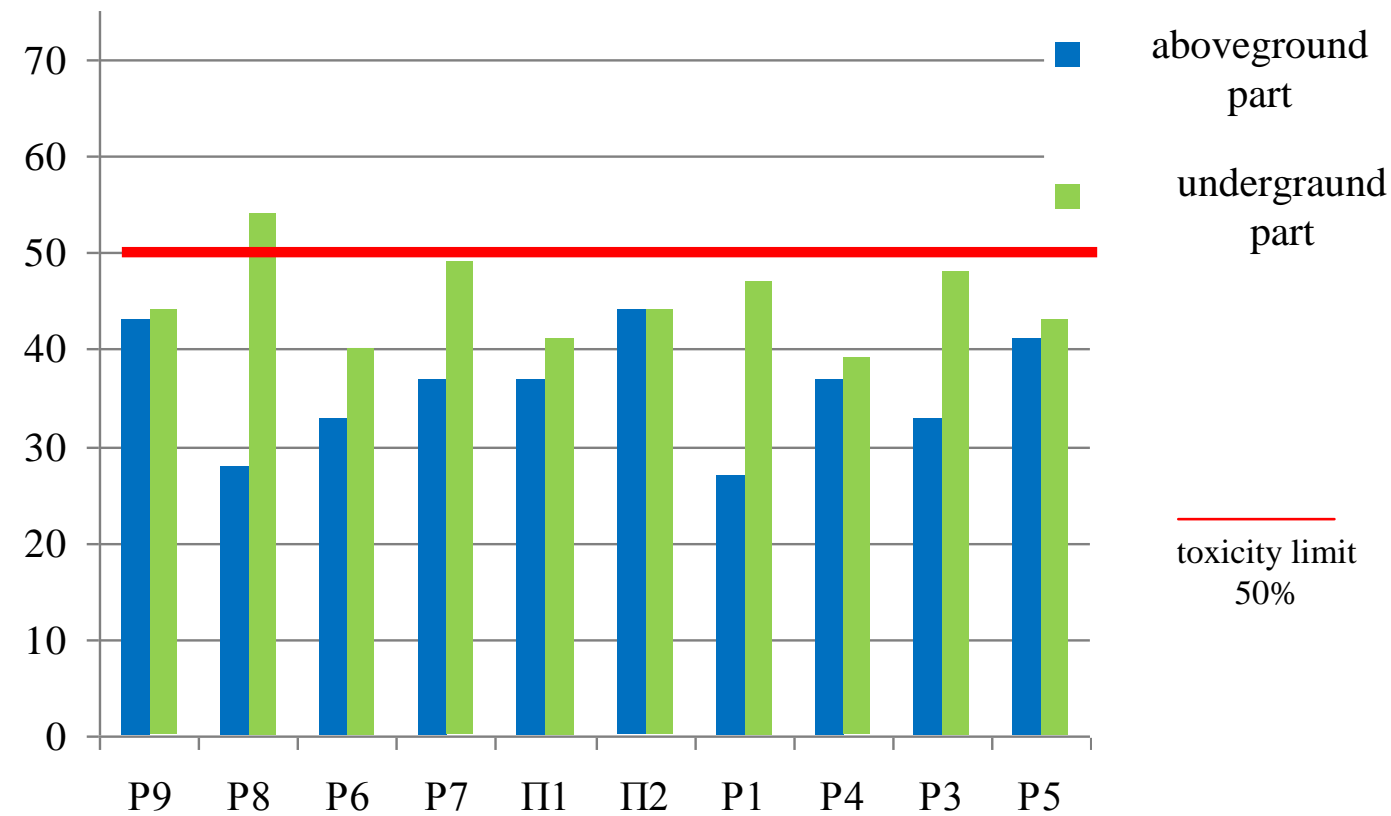

Fig. 3. Phytotoxic activity of inhibiting the growth of aboveground and underground parts of barley seedlings, $+/$ - Is and $\mathrm{Ik}, \%$

Phytotoxic activity of the underground part of barley varies within $\mathrm{Ik}=39-54 \%$. Analysis of the average values of the parameters of barley seedlings shows that the phytotoxic activity of the aboveground part of barley varies within $\mathrm{Is}=27-44 \%$.

Toxicity of soils studied for inhibition of aboveground part growth is assessed by phytotoxic activity mainly as highly toxic (Is=64-72\%). By inhibiting the growth of underground parts of wheat are moderately toxic $(\mathrm{Ik}=48-58 \%)$. With regard to barley, a non-toxic effect on phytotoxic activity was found (Is=27-44\% and $\mathrm{Ik}=39-49 \%$ ), which indicates greater resistance of barley seeds to heavy metal contamination (Table 4).
The results of research can be used in the creation of landscaping, especially at the stage of forming a range of plants, preferring those plants that are more resistant to environmental pollution. The data can also be used in measures to reduce soil phytotoxicity and streamline the city's green space system.

The high content of nutrients in samples P3, P4, P1, P6, P7 does not eliminate the toxic effects of heavy metals, plants grown on these samples are significantly inferior to control and almost do not surpass plants from variants with much lower nitrogen content. The existing level of pollution significantly determines the intensity of growth processes in plants. 
Table 4

Phytotoxic effect of HM in the soils of Odessa on the growth of barley seedlings Hordeum vulgare

\begin{tabular}{|c|c|c|c|c|c|}
\hline \multirow{2}{*}{ Soil sample } & \multicolumn{2}{|c|}{ Length, cm } & \multicolumn{3}{c|}{ Phytotoxic inhibitory activity, \% } \\
\cline { 2 - 6 } & roots & aboveground part & roots, + - Ik & aboveground part, +/- Is & half the amount \\
\hline Control & $14.03 \pm 0.21$ & $25.41 \pm 0.17$ & & & \\
\hline P9 & $11.17 \pm 0.25$ & $13.68 \pm 0.39$ & -44 & -43 & -43.5 \\
\hline P8 & $13.14 \pm 0.34$ & $9.74 \pm 0.24$ & -54 & -28 & -46 \\
\hline P6 & $10.10 \pm 0.30$ & $10.97 \pm 0.59$ & -40 & -33 & -43 \\
\hline P7 & $12.40 \pm 0.41$ & $11.58 \pm 0.45$ & -49 & -37 & -49 \\
\hline P1 & $10.87 \pm 0.28$ & $11.46 \pm 0.57$ & -41 & -37 & -44 \\
\hline P2 & $11.21 \pm 0.34$ & $13.38 \pm 0.57$ & -44 & -44 & -37 \\
\hline P1 & $11.97 \pm 0.56$ & $9.54 \pm 0.55$ & -47 & -27 & -35.5 \\
\hline P4 & $10.10 \pm 0.42$ & $12.05 \pm 0.69$ & -39 & -37 & -42 \\
\hline P3 & $12.21 \pm 0.34$ & $11.01 \pm 0.52$ & -48 & -33 & \\
\hline P5 & $11.07 \pm 0.27$ & $12.88 \pm 0.35$ & -43 & -41 & \\
\hline HIP 5 & 0.65 & 1.04 & & & \\
\hline $\mathrm{F}_{\text {studied }}$ & 17.6 & 88.6 & & & \\
\hline $\mathrm{F}_{05}$ & 1.57 & 1.57 & & & \\
\hline
\end{tabular}

It should also be borne in mind that the roots of the studied plants were generally suppressed to a greater extent than the shoots. The average phytoxicity index for shoots is $-65 \%$, for roots $-55 \%$. Imbalance in the development of underground and aboveground parts is important for tree plants used in cities for landscaping. If the root system is poorly developed compared to the aboveground part, it can lead to poor resistance of trees to wind or even spontaneous fall of trees, which is very dangerous in urban conditions. Thus, the study of the resistance of ornamental rocks to phytotoxic properties of soils can be practically valuable and relevant research.

\section{Conclusions}

The results of researches of the basic physical and chemical properties have established that the indicators of the reaction of the soil solution, the content of humus and nutrients in the soils of the parks of the city of Odessa are somewhat close to natural analogues. Anthropogenic impact on the soils of parks changes their properties. The accumulation of dust on the surface facilitates the particle size distribution. The variability of nutrient content is associated with varying degrees of anthropogenic impact on different parks. The tendency to alkalize the soil solution is also related to human activities. Regarding chemical pollution, in the park areas of the city there is an excess of several indicators - zinc and lead. In such areas, it is advisable to grow perennial grasses (lawn grasses) in order to create a continuous grass cover to reduce the risk of oral ingestion of these elements. The deterioration of the ecological situation of the city of Odessa is associated with the uneven location of indus- trial facilities in the city, a large load of vehicles. The largest amount of pollutants comes from highways. In general, the ecological situation is satisfactory, as the total indicators of $\mathrm{Cd}, \mathrm{Cu}, \mathrm{Zn}$ pollution of the soils of the parks are within the permissible (weak) level of danger, $\mathrm{Pb}$ - within the moderately dangerous level.

Conducted biotesting by the method of germination of test crops is an effective method of assessing the anthropogenic impact on soils. The study revealed plant oppression, yellowing of the aboveground part, underdeveloped seedlings of both wheat and barley. This indicates that there is an impact on the morphological and physiological characteristics of test crops of anthropogenic soil contamination of parks. Toxicity of soils studied for inhibition of aboveground growth is assessed by phytotoxic activity mainly as highly toxic (Is=64-72\%). By inhibiting the growth of underground parts of wheat are moderately toxic ( $\mathrm{Ik}=48-58 \%)$. With regard to barley, a nontoxic effect on phytotoxic activity was detected ( $\mathrm{Is}=27-44 \%$ and $\mathrm{Ik}=39-49 \%$ ), which indicates greater resistance of barley seeds to contamination by heavy metals.

The results of research can be used in the creation of landscaping, especially at the stage of forming a range of plants, preferring those plants that are more resistant to environmental pollution. The data can also be used in measures to reduce soil phytotoxicity and streamline the city's green space system.

\section{Conflicts of interest} interest.

The authors declare that they have no conflicts of

\section{References}

1. Dobrovolskii, G. V. (1997). Pochva, gorod, ekologiia. Moscow: Fond «Za ekologicheskuiu gramotnost», 320.

2. Czerwinski, Z. (1988). Soil and water relation in suburban areas of Warsaw. Natural environment of suburban areas as a development factor of big cities. Warszawa, 23-44.

3. Burghardt, W. (1996). Urbanen Bodenschutz. Berlin, 244.

4. Short, J. R., Fanning, D. S., McIntosh, M. S., Foss, J. E., Patterson, J. C. (1986). Soils of the Mall in Washington, DC: I. Statistical Summary of Properties. Soil Science Society of America Journal, 50 (3), 699-705. doi: http://doi.org/10.2136/sssaj1986.03615995005000030030x

5. Short, J. R., Fanning, D. S., Foss, J. E., Patterson, J. C. (1986). Soils of the Mall in Washington, DC: II. Genesis, Classification, and Mapping. Soil Science Society of America Journal, 50 (3), 705-710.

doi: http://doi.org/10.2136/sssaj1986.03615995005000030031x 
6. Kucheriavyi, V. P. (1999). Urboekolohiia. Lviv: Svit, 360.

7. Khokhryakova, A. I. (2016). Soils of the cities: features of genesis, classification, diagnostics. Odessa national university herald. Series: Geography \& Geology, 21 (1 (28)), 110-124. Available at: http://liber.onu.edu.ua/pdf/vestniki/ ONU_Visnik_GGF_1(2016).pdf

8. Shunelko, E. V. (2000). Ekologicheskaia otsenka gorodskikh pochv i vyiavleniia urovnia toksichnosti tiazhelykh metallov metodom biotestirovaniia. Vestnik Voronezhskogo gosudarstvennogo universiteta. Geografiia i ekologiia, 4, 77-83

9. Yakovyshyna, T. F. (2015). Ecotoxicological estimation of the city soil by the biotesting method. Universum: Khimiia i biologiia, 8 (16). Available at: https://docs.google.com/viewer?url=http://7universum.com/pdf/nature/8(16)/Yakovyshyna.pdf

10. Terekhova, V. A. (2011). Biotestirovanie pochv: podkhody i problemy. Pochvovedenie, 2, 190-198.

11. Rychak, N. L. (2009). Osoblyvosti ekolohichnoho stanu miskykh gruntiv. Liudyna i dovkillia. Problemy neoekolohii, 2 (13), 74-79.

12. Zharikova, E. A. (2014). Ekologo-geokhimicheskoe sostoianie pochv rekreatsionnykh territorii Ussuriiska. Vestnik DVO RAN, 5, 78-85.

13. Goncharenko, T. P., Zhytska, L. I. (2014). Research of urban soils quality (Cherkasy city). Visnyk ChDTU, 4, 89-94.

14. Shekhovtseva, O. G. (2011). Biological activity of the urbanized soils of Mariupol. Gruntoznavstvo, 12 (1-2), 88-91.

15. Vyal, Yu. A., Shilenkov, A. V. (2009). Evaluation of Biological Activity of Soil in Urban Areas (Zarechny Town). Izvestia Penzenskogo gosudarstvennogo pedagogicheskogo universiteta imeni V. G. Belinskogo natural sciences, 14 (18), 7-10.

16. Gorbov, S. N., Bezuglova, O. S. (2013). Biologicheskaia aktivnost pochv gorodskikh territorii (na primere g. Rostov-naDonu). Nauchnii zhurnal KubGAU, 85 (1), 1-15.

17. Terekhova, V. A. (2011). Biotestirovani pochv: podkhody i problemy. Pochvovedenie, 2, 190-198.

18. Chubyk, Z. I., Monastyrska, S. S. (2014). Otsinka stanu gruntiv m. Drohobycha metodom biotestuvannia. Biolohichni doslidzhennia - 2014. Zhytomyr: ZhDU im. I. Franka, 446-448.

19. Naleta, E. V., Kapralova, O. A., Kolesnikov, S. I., Kazeev, K. Sh. (2014). Vliianie zagriazneniia tiazhelymi metallami na biologicheskie svoistva pochv gorodov Rostovskoi oblasti. Nauka. Innovatsii. Tekhnologii, 4, 130-138.

20. Eremchenko, O. Z., Moskvina, N. V., SHestakov, I. E., SHvetsov, A. A. (2014). Ispolzovanie test-kultur dlia otsenki ekologicheskogo sostoianiia gorodskikh pochv. Vestnik TGU, 19 (5), 1280-1284.

21. Verkhoshentseva, Iu. P., Galaktionova, L. V. (2014). Fitotoksichnost pochv parkov goroda Orenburga. Vestnik OGU, 6 (167), 195-198.

22. Kisova, S. V., Bessmolnaia, M. Ia. (2010). Otsenka stepeni toksichnosti pochv urbanozemov metodom fitotestirovaniia na primere g. Ulan-Ude. Vestnik KrasGAU, 10, 119-122.

23. Yatsuk, I. P., Baliuk, S. A. (Eds.) (2019). Metodyka provedennia ahrokhimichnoi pasportyzatsii zemel silskohospodarskoho pryznachennia: kerivnyi normatyvnyi dokument. Kyiv, 108.

24. Makarenko, N. A., Makarenko, V. V. (2008). Ekolohichna ekspertyza tekhnolohii vyroshchuvannia silskohospodarskykh kultur: metodychni rekomendatsii. Kyiv: TOV «DIA», 84.

25. Furdychko, O. I. (2008). Normuvannia antropohennoho navantazhennia na navkolyshnie pryrodne seredovyshche. Kyiv: Osnova, 356.

26. Baliuk, S. A., Fatieiev, A. I., Miroshnychenko, M. M. (2004). Provedennia gruntovo-heokhimichnoho obstezhennia urbanizovanykh terytorii: metodychni rekomenditsii. Kharkiv: NNTs «IHA im. O.N. Sokolovskoho» UAAN, 62.

27. Heretsun, H. M. (2014). Vplyv ekolohichno nebezpechnykh opadiv na vlastyvosti miskykh gruntiv. Naukovyi visnyk NLTU. Ekolohiia Dovkillia, 24 (8), 106-110.

28. Vasilchenko, A. V. (2015). Otsenka toksicheskogo zagriazneniia pochv nefteproduktami v rezultate deiatelnosti avtozapravochnykh stantsii s ispolzovaniem metoda biotestirovaniia. Sovremennye problemy nauki i obrazovaniia, 2-2. Available at: https://www.science-education.ru/ru/article/view?id=20676

Received date 05.05.2020

Accepted date 09.06.2020

Published date 30.06.2020

Anastasiya Khokhryakova, Chief Soil Engineer, Odessa Branch of the State Institution «Soil protection Institute of Ukraine», Laboratorna str., 19, Limanka village, Odessa region, Ukraine, 65037

E-mail: tarleva.a.i@gmail.com 